Review

\title{
Sugarcane straw and the populations of pests and nematodes
}

\author{
Leila Luci Dinardo-Miranda*, Juliano Vilela Fracasso
}

IAC/Centro de Cana-de-açúcar, Rod. SP 333, km 321 14032-800 - Ribeirão Preto, SP - Brasil.

*Corresponding author <leiladinardo@iac.sp.gov.br>

Edited by: João Luís Nunes Carvalho
ABSTRACT: The green cane harvesting represented a significant change in sugarcane ecosystem due to the presence of straw left on the soil and to the absence of fire. These two factors may affect the populations of pests and their natural enemies. Among the pests benefit from the green cane harvesting stand out the spittlebug, Mahanarva fimbriolata, the curculionid Sphenophorus levis and sugarcane borer, Diatraea saccharalis. In areas of green cane harvesting, the population of these species grew faster than in areas of burnt cane. On the other hand, there are virtually no records of attacks by lesser cornstalk borers in areas of green cane harvesting. Populations of plant parasitic nematodes and the beetles Migdolus fryanus, very important pests of sugarcane, were apparently not affected by the green cane harvesting. Despite the absence of more consistent information, it appears that populations of ants and the giant borer Telchin licus can increase in green cane areas, due primarily to the difficulty of pest control. The partial or total removal of straw from the field represents an additional change to the ecosystem that could alter the status of pests and nematodes. It is likely that spittlebug, the curculionid S. levis and sugarcane borer populations decrease if a portion of the straw is removed from the field. However, the pest populations in areas where the straw is collected will not return to their original conditions at the time of burnt cane harvesting because the absence of fire will be maintained.

Keywords: Saccharum spp., Diatraea saccharalis, Sphenophorus levis, Manhanarva fimbriolata, Migdolus fryanus
Because straw is an excellent source of energy, studies have been conducted to evaluate the economic feasibility of removing the straw from the field for industrial energy producing (Ripoli and Ripoli, 2008). However, removing the straw from the field represents an additional change to the ecosystem that could alter the status of pests and nematodes. Thus, the second objective of this report is to discuss how this ecosystem change could affect pest and nematodes populations.

\section{Effects on the populations of root spittlebug}

The most notable change in pest populations due to the harvesting of green cane is related to Mahanarva fimbriolata Stål (Hemiptera; Cercopidae), the root spittlebug. This pest is highly dependent on soil moisture, and it is favored by hot and humid environments (Guagliumi, 1973; Dinardo-Miranda, 2003).

Due to the burning of sugarcane prior to harvest, these spittlebugs had little importance in the State of São Paulo up until the mid-1990s, and their populations remained low due to the destruction of biological forms of the pest, namely diapause eggs, by fire and the absence of straw in the cane fields (Dinardo-Miranda, 2003). At that time, root spittlebugs were economically important only in certain regions of northeastern Brazil (Mendonça, 1996).

With the adoption of mechanical harvesting of green cane, the spittlebug has rapidly spread throughout the south-central region of Brazil since the mid-1990s, benefiting from the absence of fire, which eliminates sugarcane. 
most biological forms of the pest, and the presence of straw, which helps maintain soil moisture. With this population growth, the spittlebug has spread throughout the sugarcane region and is now found not only in green ratoon sugarcane but also in burnt ratoon sugarcane and in plant cane where there is sufficient moisture for its development, even without straw, during the more intense rainy season. Thus, $M$. fimbriolata is now one of the major crop pest throughout Brazil, especially in the south-central region, where it causes sharp reductions in agricultural productivity and the quality of raw material with marked effects on industrial processes (DinardoMiranda, 2008).

The increase in spittlebug populations in areas of green cane harvesting was noted for the first areas harvested under this system. In a study conducted in Piracicaba (2243'27.94" S, 47³8'50.65" W), State of São Paulo (SP), Brazil, Macedo et al. (1997) confirmed the presence of root spittlebug nymphs during the rainiest months of the year only in areas of green cane harvesting (1.1 insect $\mathrm{m}^{-1}$ ); the authors did not find the insect in areas of burnt sugarcane harvesting. Based on surveys conducted in Dec. 2000 in the region of Guaira (SP) (20'20'6.41" S, 48 20'40.24" W), Dinardo-Miranda (2003) reported averages of 0.5 insect $\mathrm{m}^{-1}$ in burnt ratoon sugarcane and 20.2 insects $\mathrm{m}^{-1}$ in green ratoon sugarcane fields. In subsequent years, the number of reports of large root spittlebug populations in sugarcane have increased, and several studies have been conducted to establish the parameters for an integrated pest management program (Dinardo-Miranda, 2008), including the effects of cultivation measures such as the removal of the straw from the top of the cane row (Dinardo-Miranda et al., 2000; Dinardo-Miranda, 2002).

Both the presence of straw and the absence of fire have contributed to the spittlebug population increase, although the role of each of these factors is not easily measured. Guagliumi (1973) reported that M. fimbriolata females lay their eggs primarily in subsurface soil, although in the field, it is common to find adults and nymphs at approximately $10-12 \mathrm{~cm}$ soil depths, where the eggs can certainly be deposited. The fire that precedes a sugarcane harvest only heats the most superficial layer of soil (Degaspari et al., 1983); thus, only the eggs laid near the surface are likely to be destroyed by fire, and any eggs deposited in deeper layers are most likely not affected and can remain viable for the next generation. For example, Dinardo-Miranda (2003) reported that areas heavily infested by the spittlebug had large populations of the species in the subsequent ratoon cane, even after being subjected to burnt cane harvesting.

Currently, in hot and humid regions, where it is favorable to the successful development of the pest, it is common to find large populations of spittlebug in burnt sugarcane areas. Therefore, fire exerts a certain negative pressure on spittlebug population, although the absence of fire is not the only factor contributing to the spread of the spittlebug with green cane harvesting. The presence of straw also plays an important role, as demonstrated in experiments conducted by Dinardo-Miranda (2002) in which the straw layer was removed or separated from the top of the cane row.

The practice of lining up the straw between the cane rows, leaving the rows straw-free, could be effective in the maintenance of a low spittlebug population throughout the entire duration of its occurrence if the infestation rate is not excessively high (Dinardo-Miranda, 2002). This effect occurs because the removal or separation of the straw allows a higher incidence of solar radiation on the cane rows with a consequent decrease in soil moisture, resulting in less favorable conditions for pest development.

Dinardo-Miranda (2002) reported that the densities of spittlebug infestations in samplings conducted in Dec. 2000, Jan. 2001 and Feb. 2001 were 5.6, 6.9 and 16.0 insects $\mathrm{m}^{-1}$, respectively, in the plots where straw was not removed and 1.8, 0.9 and 4.6 insects $\mathrm{m}^{-1}$, respectively, in plots where the straw was lined up between the cane rows. In other areas, the removal of straw reduced the spittlebug populations by approximately $85 \%$ during the population peak, from 20.2 insects $\mathrm{m}^{-1}$ in areas with straw to 2.7 insects $\mathrm{m}^{-1}$ in the areas in which the straw was removed (Dinardo-Miranda, 2002). According to the author, in fields with very high infestations, the removal of straw helped to reduce the pest population, although the populations generally remained at concerning levels. This was noted in an experiment in which spittlebug populations were 58 insects $\mathrm{m}^{-1}$ in the control treatment (with straw) and 26 insects $\mathrm{m}^{-1}$ in the treatment with straw removal. The author cautioned that although the populations in both conditions were significantly different, infestations in areas where straw was removed $(26$ insects $\mathrm{m}^{-1}$ ) continued to be sufficiently high as to cause damage to the crop; Dinardo-Miranda also stressed that in plots with a history of high population density, the removal of straw alone would not be an effective control measure.

It is likely that spittlebug populations decrease if a portion of the straw remaining from a green cane harvest is removed from the field. The decrease is more pronounced when less straw remains in the area. Because the soil moisture level is lower in areas with little or no straw, the onset of the occurrence of the spittlebug may be delayed in those areas until the rainy season increases soil moisture to a level adequate for the proper development of the spittlebug. As a consequence of this delay in the pest development, the damage caused by spittlebugs will tend to be less because the populations reach an economic injury level at a later point in the season, when the plants are more developed. According to Dinardo-Miranda (2003), larger plants have a greater capacity to tolerate the damage caused by a spittlebug attack. In addition, the removal of part or all of the straw from the sugarcane fields may also affect crop development. In warmer and drier regions, sprouting and the initial development of certain cultivars, especially those harvested between 
Jun. and Sep., can be severely hindered by the removal of straw due to the decreased soil moisture in the cane rows. The damage to the initial development of the crop is often reflected in lower agricultural productivity and is quite marked in drier years or in acrid soils. In these situations, the potential benefits of straw removal with respect to spittlebug populations would be offset by the impairment of the ratoon development.

\section{Impact on the populations of Sphenophorus levis}

Although the importance of root spittlebug in the green cane areas is undeniable, another pest, Sphenophorus levis Vaurie (Coleoptera: Curculionidae), has been the cause of much concern among producers and researchers. Until the late 1970s, S. levis was restricted to the region of Piracicaba, State of São Paulo (Precetti and Arrigoni, 1990) but, since that time, it has spread to other sugarcane-producing regions via stalks taken from infested locations and used for planting elsewhere in the region. The adults are very long-lived and roam on the ground, where they protect themselves under crop residues and weeds (Precetti and Arrigoni, 1990). When the burnt sugarcane harvesting method is used, many pest adults die due to fire. With green sugarcane harvesting, in addition to the lack of mortality of adults by fire, the straw remaining in the field acts as their shelter. Thus, with the increase in green cane harvesting, populations rapidly increased, and in some regions, the sugarcane fields were decimated within one or two harvests, as reported by Dinardo-Miranda $(2000,2011)$ and Arrigoni (2011). Because the adopted control measures are inefficient (Dinardo-Miranda, 2000; 2008), the problem tends to worsen over time.

The effect of green cane harvesting on the populations of $S$. levis was clearly demonstrated in the study of Dinardo-Miranda (2009), in which two treatments were evaluated in an infested ratoon crop: manual harvesting of burnt sugarcane and mechanical harvesting of green sugarcane. In the sampling performed prior to the harvest, when the treatments had not yet been applied, similar insect populations and levels of rhizome damage were found both in the plots where green cane would be harvested and in plots intended for manual harvesting of burnt cane, showing that there was no initial difference between the plots (Figure 1). This finding was expected because plots had received the same treatment had been applied to both plots up to that time. However, in the samples collected two and four months after harvesting, the populations of $S$. levis and the degree of pest damage were greater in the green cane areas $(p<0.1)$, showing that this harvesting system promotes a rapid increase in the pest population.

The removal of straw from the field may reduce the rate of $S$. levis population, although this reduction is likely to be small because the removal results in fewer available shelter areas for adults. Because the adults are highly resistant to adverse conditions (Precetti and Arrigoni, 1990), this measure has little impact because the

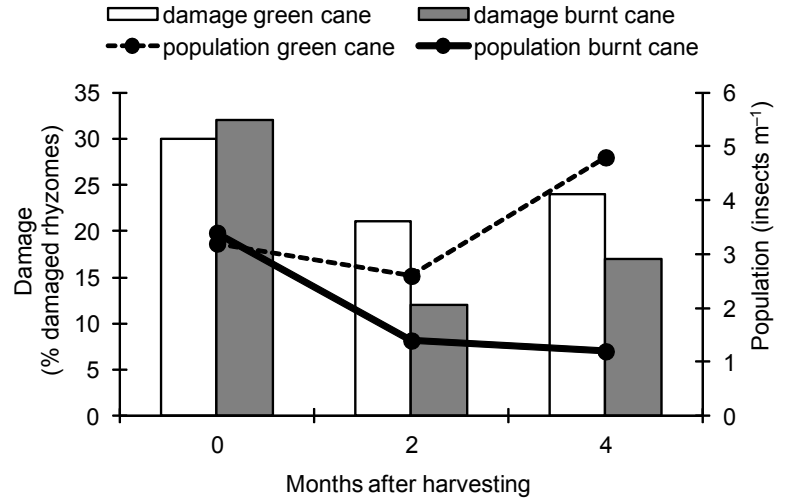

Figure 1 - Population of Sphenophorus levis and damage caused by the pest in sugarcane field under two harvesting systems (adapted from Dinardo-Miranda, 2000).

absence of fire is maintained in this scenario. The absence of fire, which eliminates many of the adults that roam on the soil, appears to be the most significant factor for the increase of $S$. levis populations in areas of green cane harvesting. However, studies are needed to better assess the impact of straw removal on $S$. levis population and the degree of pest damage.

\section{Impact on the sugarcane borer populations}

The effects of green cane harvesting on the populations of the sugarcane borer, Diatraea saccharalis Fabricius (Lepidoptera; Crambidae), one of the most important sugarcane pests in Brazil (Botelho and Macedo, 2002; Dinardo-Miranda, 2008), have generated great interest among researchers and producers due to the role played by natural enemies, which act on all of the biological stages of this borer. Although the role of natural enemies varies with location and year, they destroy approximately $80 \%$ of the eggs laid by females (Terán, 1980; Degaspari et al., 1987), and approximately $20 \%$ of the remaining caterpillars (Botelho and Macedo, 2002), and both pupae and adults (Almeida et al., 1986).

In a study conducted in the mid-1990s, Araújo and Macedo (1998) collected arthropods using light traps and trip-fall traps and performed several other population surveys to test for differences between a sugarcane field subjected to green cane harvesting and another subjected to burnt cane harvesting. The authors found that the insect populations, namely the predator and parasitoid insect populations, were larger and more diverse in the area of green cane harvesting. Due to that finding, Araújo and Macedo concluded that the burning of the sugarcane fields for harvesting was harmful to the natural enemies of $D$. saccharalis, resulting in a biological imbalance and significant increases in the pest population.

Based on those results, Macedo (2005) suggested that the problems associated with the sugarcane borer would tend to decrease with the adoption of green cane harvesting due to the greater effect of predators and 
parasitoids relative to the burnt sugarcane environment. However, this expectation was not confirmed, and with the adoption of green sugarcane harvesting in large areas in recent years, a better understanding of the situation is now possible.

A strong tendency of $D$. saccharalis populations to increase in areas of green cane harvesting was observed by Arrigoni (2011) based on surveys conducted in various regions for several years. An analysis of data from surveys performed during harvest in a company of the the Ribeirão Preto region (218'42.50" S, 47 48'44.04" W), SP, Brazil, in which approximately 80,000 ha are cultivated with sugarcane, showed an increased intensity of the infestation when the total area of green cane harvesting was increased (Figure 2).

The intensity of infestation, expressed as the percentage of bored internodes, is surveyed during the harvest period and measures the damage caused by the pest during the crop development (Dinardo-Miranda, 2008). Therefore, this index reflects the pest populations that occur throughout the year.

Many factors affect the $D$. saccharalis population and thus the intensity of infestation, including the adopted cultivars, temperature and moisture conditions (especially rain) throughout the year and population of natural enemies among others (Dinardo-Miranda, 2008). In the presented study (Figure 2), however, the different varieties exhibited little variation in the evaluated period; similarly, there were no marked changes in the weather conditions that could explain such an increase in the populations of sugarcane borer population. The most striking change was the transition to green cane harvesting. In the studied area, no pest control measures were implemented until 2008. In 2008 and 2009, releases of Cotesia flavipes (Cameron) (Hymenoptera, Braconidae) and applications of chemical insecticides were performed to reduce $D$. saccharalis populations during the period of crop development, which helped reduce the infestation levels in the subsequent seasons (2009 and 2010).

Even considering the pest control measures implemented in 2008 and 2009, which affected the infestation intensity at harvest in the following years, there is a strong relationship between the green cane harvesting and the infestation intensity index. The curve that best defines this relationship is given by $y=0.0556 x$ +3.2248 , where $y$ is the infestation intensity expressed as a percentage of bored internodes and $\mathrm{x}$ is the area of green cane expressed as a percentage of harvested area. The $\mathrm{r}^{2}$ of the curve is 0.7511 with $\mathrm{F}=9.055$ and a significance of $p=0.05$ (Figure 3 ).

Green sugarcane harvesting may have benefited the entomofauna of the sugarcane field, thereby contributing to increased populations of parasitoids and predators of the borer, as found by Araújo and Macedo (1998). However, the increasing intensity of infestation indicates that the harvest of green cane was proportionally more beneficial to the pest. The effect on the populations of parasitoids, predators and borer of the eventual removal of the straw deposited on the field requires further investigation, although this impact is likely to be small. The absence of fire likely had the greatest contribution to the arthropod population increases in areas of green sugarcane, whereas the presence of straw probably had a lesser impact.

\section{Impact on populations of other pests and plant- parasitic nematodes}

Studies on the impact of green cane harvesting on the populations of other important pests such as Migdolus fryanus Westwood (Coleoptera: Cerambicidae), termites and plant-parasitic nematodes have not been reported to date. All of these organisms inhabit in the soil or on roots and were apparently affected to only a small extent by green cane harvesting.

Termites are decomposers of organic matter, and thus, it was expected that their populations would in-

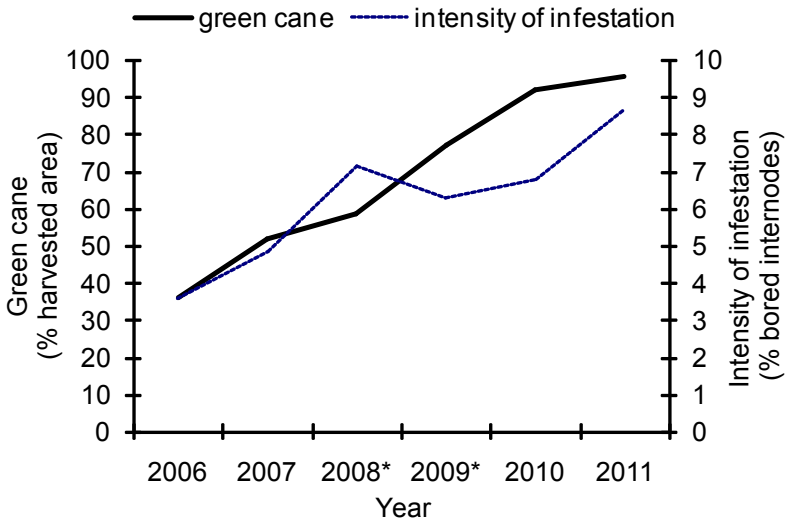

Figure 2 - Proportion of green cane harvesting area and intensity of infestation of Diatraea saccharalis in sugarcane mill at Ribeirão Preto region, Brazil. * Years when chemical and biological control were adopted.

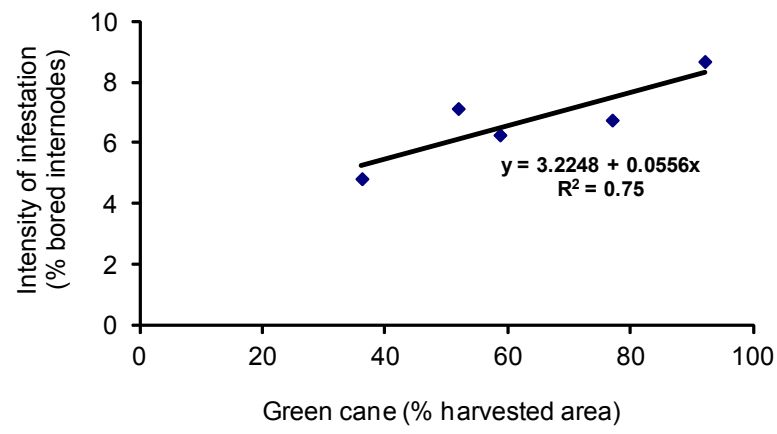

Figure 3 - Relationship between green cane harvesting and intensity of infestation (II, expressed as a percentage of bored internodes) of Diatraea saccharalis in sugarcane mill at Ribeirão Preto region, Brazil. 
crease due to a greater availability of straw. However, surveys conducted periodically by sugarcane producers to assess the occurrence of termites in their areas have not shown population growth. It must be considered that the most important pests of sugarcane in the central-south region is Heterotermes tenuis, which feeds on live material (Dinardo-Miranda, 2008), and thus, large deposits of straw should not affect their populations. Therefore, even if the straw contributes to termite population increases, the populations of the most important species, $H$. tenuis, should not change as a function of the presence of straw.

With respect to nematodes, there could be a suppression of populations resulting from the increase in organic matter on the soil due to the deposition of straw. This suppression would occur because the organic matter allows for the growth of other microorganisms that affect the nematode population. Moreover, substances with nematicidal effects are released during the decomposition of organic matter (Lordello, 1981). In sugarcane fields, however, changes in nematode populations have not been observed after the addition of organic matter such as filter cake (Novaretti and Nelli, 1985; DinardoMiranda et al., 2003). Thus, it is likely that straw does not significantly affect the populations of nematodes, at least in the short term. To date, problems due to high nematode populations continue to be reported even in areas of green cane.

It is believed that the populations of certain pests may increase due green cane harvesting (Macedo, 2005; Arrigoni, 2011) despite the lack of studies on this topic. One of these pests is the giant sugarcane borer, Telchin licus (Drury) (Lepidoptera: Castniidae), which is an important pest in northeastern Brazil and that was reported in São Paulo in 2007 (Almeida et al., 2007). Green cane harvesting can benefit this pest mainly by the elimination of fire, which is responsible for the destruction of adults. Moreover, the straw remaining in the field after green cane harvesting hinders pest control, which in northeastern Brazil is performed by the collection of caterpillars and pupae on the underground portion of the plants immediately after harvesting (Dinardo-Miranda, 2008). Therefore, the deposited straw would make it difficult to identify infested ratoons.

Populations of leaf-cutter ants may also increase with green cane harvesting because the straw hunders pest control by making it difficult to identify and quantify the nests. Moreover, when pest control is performed via thermal fogging, this practice becomes dangerous due to the fire risk (Macedo, 2005; Arrigoni, 2011).

The only record of pest population reduction due to green cane harvesting corresponds to the lesser cornstalk borer, Elasmopalpus lignoselus (Zeller) (Lepdoptera: Pyralidae), a pest that occurs sporadically in periods of prolonged drought (Macedo, 2005; Arrigoni, 2011). In areas of green sugarcane cultivation, there are virtually no records of attacks by lesser cornstalk borers.
The effects of green cane harvesting on populations of lesser cornstalk borers were observed by Macedo et al. (1997) in a study in the State of São Paulo. The authors found a significant reduction in lesser cornstalk borer attacks in an area of green harvesting relative to an area of burnt cane harvesting. According to these authors, this correlation was likely associated with the oviposition habits of adults, who are strongly attracted by the smoke.

\section{Final considerations}

If green cane harvesting causes changes in the ecosystem due to the absence of fire and presence of straw, directly and indirectly affecting pests and nematodes that are important for sugarcane, the partial or total removal of straw represents a new type of change. However, it is likely that the pest populations in areas where the straw is collected will not return to their original conditions at the time of burnt cane harvesting because the absence of fire will be maintained. The new scenario will be represented by a cane field with no burning and no straw, and certain species may benefit or be harmed to a greater or lesser extent by the removal of straw. Further studies on this topic are needed.

\section{References}

Almeida, L.C.; Botelho, P.S.M.; Pavan, O.H.O. 1986. Avaliação do vírus da granulose para o controle da broca da cana-de-açúcar = Avaliation of granulosis virus to sugarcane borer control. p. 203209. In: Alves, S.B. Controle microbiano de insetos $=$ Microbial control of insects. Manole, São Paulo, Brazil (in Portuguese).

Almeida, L.C.; Dias, M.M.; Arrigoni, E.B. 2007. First ocorrence of Telchin licus licus (Drury, 1773), the sugarcane giant borer, in São Paulo State. Revista de Agricultura 82: 233-236 (in Portuguese, with abstract in English).

Araújo, J.R.; Macedo, N. 1998. Effect of sugarcane burning on sugarcane borer Diatraea saccharalis (Fabr. 1794) and its major natural enemies. STAB - Açúcar, Álcool e Subprodutos 16: 3034 (in Portuguese, with abstract in English).

Arrigoni, E.B. 2011. New pests of the new system. Revista Opiniões 28: 65-67.

Botelho, P.S.M.; Macedo, N. 2002. Cotesia flavipes para o controle de Diatraea saccharalis = Cotesia flavipes to Diatraea saccharalis control. p. 409-425. In: Parra, J.R.P.; Botelho, P.S.M.; CorreaFerreira, B.S.; Bento, J.M.S. Controle biológico no Brasil: parasitóides e predadores $=$ Biological control in Brazil: parasitoids and predators. Manole, São Paulo, Brazil (in Portuguese).

Degaspari, N.; Botelho, P.S.M.; Almeida, L.C.; Macedo, N.; Araújo, J.R. 1983. Sugarcane burning, effects on populations of Diatraea saccharalis (Fabr., 1794) and its parasitoids and predators. STAB - Açúcar, Álcool e Subprodutos 1: 35-40 (in Portuguese, with abstract in English).

Degaspari, N.; Macedo, N.; Botelho, P.S.M.; Araujo, J.R.; Almeida, L.C. 1987. Predators and eggs parasitoids of Diatraea saccharalis in sugarcane. Pesquisa Agropecuária Brasileira 22: 785-792 (in Portuguese, with abstract in English). 
Dinardo-Miranda, L.L. 2000. Ocorrência de Sphenophorus levis em $2000=$ Sphenophorus levis ocurrence in 2000. STAB - Açúcar, Álcool e Subprodutos 19: 26 (in Portuguese).

Dinardo-Miranda, L.L. 2002. O papel da retirada da palha no manejo da cigarrinha-das-raízes $=$ The role of removing straw on spittlebug management. STAB - Açúcar, Álcool e Subprodutos 20: 23 (in Portuguese).

Dinardo-Miranda, L.L. 2003. Cigarrinha-das-Raízes em Canade-Açúcar = Spittlebugs in Sugarcane. Instituto Agronômico, Campinas, Brazil (in Portuguese).

Dinardo-Miranda, L.L. 2008. Pragas = Pests. p. 349-404. In: DinardoMiranda, L.L.; Vasconcelos, A.C.M.; Landell, M.G.A., eds. Canade-açúcar $=$ Sugarcane. Instituto Agronômico, Campinas, Brazil (in Portuguese).

Dinardo-Miranda, L.L. 2009. Cana crua e Sphenophorus levis = Green cane and Sphenophorus levis. STAB - Açúcar, Álcool e Subprodutos 27: 23-24 (in Portuguese).

Dinardo-Miranda, L.L. 2011. Pests and the green sugarcane scenario. Revista Opiniões 28: 62-64.

Dinardo-Miranda, L.L.; Ferreira, J.M.G.; Durigan, A.M.P.R.; Barbosa, V. 2000. Efficiency of insecticides and cultural pratices on Mahanarva fimbriolata control in sugarcane. STAB - Açúcar, Álcool e Subprodutos 18: 34-36 (in Portuguese, with abstract in English).

Dinardo-Miranda, L.L.; Gil, M.A.; Coelho, A.L.; Garcia, V.; Menegatti, C.C. 2003. Effect of filtercake and nematicides on nematode population and sugarcane yield. Nematologia Brasileira 27:61-67 (in Portuguese, with abstract in English).

Guagliumi, P. 1973. Pragas da cana-de-açúcar: Nordeste do Brasil = Pests of sugarcane: Northeast of Brazil. IAA, Rio de Janeiro, Brazil (in Portuguese).
Lordello, L.G.E. 1981. Nematóides das plantas cultivadas = Nematodes of cultivated plants. Nobel, Piracicaba, Brazil (in Portuguese).

Macedo, N. 2005. Colheita de cana queimada versus crua e populaçoes de insetos e pragas $=$ Burned and green sugarcane harvesting and pests and insects population. Revista Opiniões 5: 32 (in Portuguese).

Macedo, N.; Campos, M.B.S.; Araújo, J.R. 1997. Insects on roots and plant lap, tillering and yield of green and burned cane. STAB - Açúcar, Álcool e Subprodutos 15: 18-21 (in Portuguese, with abstract in English).

Mendonça, A.F. 1996. Pragas da Cana-de-Açúcar = Pests of Sugarcane. Insetos e Cia, Maceió, Brazil (in Portuguese).

Novaretti, W.R.T.; Nelli, E.J. 1985. Use of nematicide and filtercake for control of nematodes attacking sugarcane in São Paulo State. Nematologia Brasileira 9: 175-184.

Precetti, A.A.C.M.; Arrigoni, E.B. 1990. Bioecologia e controle do besouro Sphenophorus levis Vaurie, 1978 (Coleoptera: Curculionidae) $=$ Bioecology and control of the bettle Sphenophorus levis Vaurie, 1978 (Coleoptera: Curculionidae). Copersucar, São Paulo, Brazil (in Portuguese).

Ripoli, M.L.C; Ripoli, T.C.C. 2008. A palha como fonte de energia = Staw as a power source. p. 349-404. In: Dinardo-Miranda, L.L.; Vasconcelos, A.C.M.; Landell, M.G.A., eds. Sugarcane. Instituto Agronômico, Campinas, Brazil (in Portuguese).

Téran, F.O. 1980. Natural control of Diatraea saccharalis (F., 1794) eggs in sugarcane fields of São Paulo. p. 1704-1714. In: Proceedings of the $17^{\text {th }}$ Congress of International Society of Sugarcane Technologists, Manila, Filipinas. 